\title{
A MEXICAN CONQUEST OF SPACE \\ Cosmopolitanism, Cosmopolitics, and Cosmopoetics in the Mexican Space Industry
}

In the wake of human space exploration, Hans Blumenberg proposed the creation of a new field of study that would strike a balance between "centrifugal curiosity" and "centripetal care." He called this field astronoetics, distinguished from astronautics as a way of critically imagining extraterrestrial travel and other activities, neither dismissing outer space as a destination, nor abandoning humanity's ethical commitments to its home planet (Harries 320). In this paper, I propose a Mexican astronoetics: a way of recognizing the extraterrestrial aspirations of many Mexicans, while at the same time critically reflecting on the notions of exploration and conquest that inform these aspirations, as well as the earthly limits that complicate the possibility of their achievement.

Before l look at the inter- and transnational relationships required to participate in outer space activities, I find it useful to think through some spatio-political concepts that are being debated in the era of the Blue Dot: globalization, cosmopolitanism/cosmopolitics, and the planetary, all of which demand that attention be paid to the ways in which humans (and non-humans) interact across Earth, and the ways in which these interactions are facilitated, negotiated, monitored, channeled and/or obstructed. "Globalization" refers to the processes that produce networks, particularly of capital, that connect people, places and things all over the planet. Some authors write of globalization as a positive process that connects

Anne Warren Johnson

Universidad Iberoamericana

Ciudad de México México 
social actors and facilitates communication and understanding across cultural boundaries, while others emphasize the partiality and inequality of these connections, describing the ways in which the benefits of globalization are differentially distributed around the world (Matthews, at al., 2012). Globalization requires, obviously, "globalism," a notion of the world as a globe. According to Ingold, the modern idea of the world-as-globe is a colonial product, a "surface waiting to be occupied, to be colonized first by living things and later by human (usually meaning Western) civilization" (Ingold 2000: 214). "Once the world is conceived as a globe," Ingold goes on to note, "it can become an object of appropriation for a collective humanity" (2000: 214). Another response to a perceived overemphasis on the notion of the globe comes from Spivak (2003: 72), who argues for the notion of the 'planetary' as a substitute for the global. Unlike the canny inhabitability of Ingold's encompassing spheres, the planetary, for Spivak, is uncanny: both same and other, familiar and unfamiliar, inhabited and uninhabitable, necessary and impossible.

As Walter Mignolo has pointed out, it becomes necessary to recognize that old cosmopolitanism was the product of privileges that were only made possible within Western colonialism (2011: 44). For Mignolo, all cosmopolitanisms are necessarily local; instead of the detachment that Heidegger feared would be a consequence of space exploration, they involve multiple attachments, re-attachments, or "attachments at a distance"

One World

The Americas

Everywhere (Robbins 1998: 3). An acknowledgement of the (non-exclusive) situatedness of the cosmopolitan represents an important corrective to the utopian view of a borderless and nationless world and is mirrored by the recent turn toward 'decolonial cosmopolitanism,' 'cosmopolitanism from below,' 'discrepant cosmopolitanisms,' and 'vernacular cosmopolitanisms'-or, as defined by Gustavo Lins Ribeiro, cosmopolitics: "a critical and plural perspective on the possibilities of supra- and transnational articulations" which supplements the notion of cosmopolitanism with "an analysis in which power asymmetries are of fundamental importance" (2008: 34). The notion of cosmopolitics, with its tension between

1. Dipesh Chakrabarty (2000) also argues for the necessity of "provincializing Europe." 
the cosmos (open, expansive, subjunctive, beyond) and the polis (relations, localities, memberships, borders) allows for a rethinking of cosmopolitization as a process that inevitably questions the notion of the shared, the commons, the "us," while leaving a kind of "speculative" (Stengers 2011: 356) space for the possible. As Bruno Latour puts it, "Cosmos protects against the premature closure of politics, and politics against the premature closure of cosmos" (2004: 454).

Mexico is illustrative of the spatial and temporal heterogeneity of modernity. On the one hand, the borders of the nation-state are extremely visible, physically and discursively, and national identity, constructed on a particular history of indigenous culture, conquest, colonialism and autonomy, continues to be a powerful force. On the other, Mexico has always been a country of flows: the movement of people, objects and ideas has been fundamental in its social, economic and political development. "So far from God, so close to the United States," as the saying goes, Mexico troubles the traditional distinctions between first and third worlds, east and west, north and south, centers and peripheries.

\section{THE SPACE RACE: BEYOND THE BINARY}

One of the most important moments for the history of space exploration, but also for global collaboration and international relations, was the International Ceophysical Year (ICY), 1957-1958. Sixty-seven countries, including Mexico, and nearly 80,000 scientists participated in this international project to study the Earth as part of a much larger cosmic system. Along with important scientific advances in geo- and astrophysics like the discovery of the Van Allen radiation belt, one of the most important achievements during this year was the launching of the first artificial satellites: Sputnik 1 and 2 by the Soviet Union, and Explorer 1 by the United States, marking the beginning of the "space race." Spurred in part by the Soviet Union's technological advances, NASA (the National Aeronautics and Space Administration) was created by the US government in 1958. The space race notwithstanding, at the inauguration of the IGY, US President Dwight D. Eisenhower declared that "[...] the most important result of the International Ceophysical Year is the demonstration of the ability of peoples 
of all nations to work together harmoniously for the common good" (Kohut 2008: 30), and NASA included an Office of International Cooperation from its inception.

National committees formed the basis for the planning and organization of the activities of the IGY. In Mexico, scientists under the leadership of the director of the recently created Institute of Ceophysics of the National Autonomous University (UNAM) participated in the establishment of new oceanographic and meteorological research stations, gravimetrical expeditions to Central and South America, the observation of solar activity (due to a peak in the eleven-year solar cycle, the aurora borealis was visible even in Mexico during the IGY), atmospheric and seismological studies, among other projects (Urrutia 1999: 129). Mexico was also designated the seat of the Pan-American Committee for the IGY by the Pan-American Institute of Geography and History of the Organization of American States.

The launching of Sputnik-1 was reported on Mexican television on the same day as the launch and marked the start of the space race for most Mexicans. Celeste González de Bustamante points out that while many Latin American news outlets praised Soviet technological capacity, they also unfavorably compared the openness of U.S. space efforts with the secrecy of the Soviet Union (2012: 112-115). Mexican journalists would soon begin to speculate about the possible military uses of satellite technology in the context of the Cold War, which they described as "a balance of terror"

One World The Americas Everywhere (121). Regardless of those fears, four years after Sputnik, Mexicans would marvel at Soviet advances in space technology when Yuri Gagarin became the first person to orbit the Earth in April of 1961. Gagarin and Valentina Tereschkova, the first woman in space, visited Mexico in 1963 as part of a hugely successful world tour. Tereshkova called for world peace, declaring that seeing the Earth from orbit provides a different, cosmic perspective, and Gagarin argued that "cosmic dominion for the benefit of humanity" would be achieved much more quickly if all countries worked together, "in peaceful collaboration" and without "bellicose objectives."

2. Gagarin and Tereshkova were not the only Soviet heroes honored in Mexico. Writer Carlos Olvera, inspired like many other Mexicans by the space 
However, Cold War competition for getting to the Moon was fierce. Six years after the cosmonauts' visit to Mexico, Mexican journalists would travel to Houston to witness the first Moon landing, an event which also saw the first images of space transmitted live, simultaneously to countries around the world (González de Bustamante 2012: 135-139). On Mexican television, transmitting to most of the 4.5 million television sets throughout the country (half of them in Mexico City) newscasters emphasized the uses of space technology for peace. It is important to recognize the international efforts that surrounded the Apollo Mission, including activities that were undertaken in Mexico before the mission, like the use of the volcanic fields of the Pinacate Biosphere Reserve in Sonora as a Moon analog for training Apollo astronauts (Arreola Santander 2017), and the distribution of hundreds of samples of moon rock after the mission for public viewing and scientific research all over the world (Krige 2013: 4). International relations aside, the fact that the flag Armstrong planted on the Moon was from the United States, not the United Nations, did not go unnoticed.

INTERNATIONAL LAW

The discourse of universal peace and human progress was tempered by the fear and unease inspired by what appeared to be an escalating arms race between the United States and the Soviet Union: the first international treaty regulating the uses of outer space was signed in 1967, after being approved by the General Assembly of the United Nations. ${ }^{3}$ Ratified by 109 countries, including the United States and the Soviet Union (as well as Mexico), the Outer Space Treaty dealt fundamentally with arms-control

flight and death of the dog Laika, dedicated his 1968 science fiction novel, Mejicanos en el espacio, to "Laika, the Pioneer."

3. That same year, Mexican President Gustavo Díaz Ordaz proposed an international treaty for the disarmament of Latin America and the Caribbean in response to the Cuban Missile Crisis. The "Treaty for the Proscription of Nuclear Arms in Latin America and the Caribbean", better known as the Treaty of Tlatelolco, was signed by twenty-one Latin American countries and entered into force in 1969. As was the case for the Non-aligned movement, the countries who prepare the most for the consequences of global wars may be those least responsible for waging them. 
in the context of the Cold War and did not provide any legal orientations for more recent commercial activities in space (UNOOSA 2017). A second treaty was developed decades later by the Committee on the Peaceful Uses of Outer Space (COPUOS) to deal with more specific cases and procedures. The agreement bans weapon testing, nuclear weapons in orbit and military bases on celestial bodies; provides for the equitable sharing of natural lunar resources among all countries; establishes freedom of scientific research on the Moon and suggests that scientific samples be made available to all countries for research purposes; prohibits ownership of property in space; ensures that non-governmental organizations can only engage in activities on celestial bodies with the authority of "the appropriate state party," and demands that any activities on the Moon be reported to the United Nations (UNOOSA 2017: 36-37). The five signatures required were obtained in 1984, and it entered into force that year for the signatories. Mexico ratified the treaty in 1981. However, the only country with independent spaceflight capabilities to sign the treaty was India, which has yet to ratify it, while the United States, the Russian Federation and the People's Republic of China have, so far, refused to sign (Listner 2011).

Although it might seem that developing nations have the most to gain from declaring outer space to be "the common heritage of humankind," one resource has been claimed by a group of developing countries. Ceostationary orbit (CEO), a band of space

One World The Americas Everywhere 36,000 kilometers above Earth's equator, is valuable real estate. A satellite in GEO orbits at the same speed as the Earth's rotation, and therefore stays over a fixed point on the Earth's surface. Telecommunication satellites, for example, use GEO to transmit to specific regions. Orbital slots, however, are limited. In 1976, eight states located at the equator asserted that the orbital slots located at their coordinates formed part of their national resources; their national borders should extend upwards beyond the Kármán line, which marks the border between Earth's atmosphere and outer space at 100 kilometers above sea level. In this sense, the Outer Space Treaty, which declared that outer space could not be appropriated by particular states, did not protect their interests. Through the Bogotá Declaration, Colombia, Ecuador, Congo, Indonesia, Kenya, 
Uganda and Zaire, with Brazil observing, attempted to categorize the GEO as a natural resource, part of Earth rather than a region of space, which would allow its signatories time to achieve the technological and economic means to occupy those slots before they were occupied by states of the global north. ${ }^{4}$ Today, however, out of 562 satellites in CEO, only a handful belong to equatorial states. Mexico is not an equatorial state, but it does have access to four geostationary orbits. Mexican satellites, both corporate and governmental, were designed and built outside the country.

\section{MEXICO ENTERS THE SPACE RACE}

In December of 1957, two months after Sputnik reached orbit, a team of physicists from the University of San Luís Potosi launched the first Mexican rocket, powered by solid combustible fuel, into the atmosphere from a desert region inhabited primarily by nopal plants that would later be baptized 'Cabo Tuna,' or 'Cape Prickly Pear,' in a tongue-in-cheek reference to Florida's Cape Kennedy. The Secretary of Communications and Transportation (SCT) followed two years later with the construction of rockets using liquid fuel, following the example of World War II German rockets (Montaño Barbosa 2015). One of these rockets, named "Arrow-2" (Mitl-2 in Nahuatl), reached an altitude higher than the Kármán line.

The Mexican government also participated in the space race by signing an agreement with NASA, allowing for the construction of a tracking station in Guaymas, Sonora, which was used from 1958-1963 in support of the United States' Project Mercury orbital space flights. Mexican television, dependent on satellite technology, proudly reported on these efforts as a way of showing that Mexico was modernizing. On June 26, 1961, the day of the station's inauguration, Noticiero aerovanes reported that Mexico was cooperating with the United States in a project that had no warl like

4. Even today, the Columbian constitution states that "Also part of Colombia is the subsoil, the territorial sea, the contiguous zone, the continental shelf, the exclusive economic zone, the airspace, the segment of the geostationary orbit, the electromagnetic spectrum and the space in which it operates, in accordance with international law or the laws of Colombia in the absence of international regulations." Tellingly, Colombia has signed, but not ratified, the Outer Space Treaty (Durrani 2018). 
intentions (González de Bustamante 2012: 127). ${ }^{5}$ This statement in particular was included to appease those opponents of the project who felt that it went against Mexico's vow to "remain neutral in the face of international conflict," and others who feared it could have military purposes (Conzález de Bustamante 2012: 25). President Kennedy enjoyed great support in Mexico, but many Mexicans decried Kennedy's policies in Cuba, particularly the Bay of Pigs invasion that had occurred two months earlier (Conzález de Bustamante 2012: 129). In 1962, President Adolfo López Mateos created the National Commission for Outer Space, or CONEE, Mexico's first governmental space organization, to support research on rockets, telecommunications and atmospheric studies. That same year saw the creation of the Department of Outer Space (now the Department of Space Science) at UNAM's Institute of Geophysics, oriented toward the study of astrophysics. In 1977, however, after the economic crisis of 1976, President José López Portillo dissolved the CONEE.

In 1985, through an agreement with NASA, the Mexican government put the Morelos I and II telecommunications satellites in orbit and sent the first Mexican citizen into space. In 1994 , UNAM scientists designed and built the scientific research satellites UNAMSAT-1 and UNAMSAT-B, both launched from the Russian Federation, designed to study the trajectories of meteor impact on Earth. UNAMSAT-1 was destroyed during a launch mishap.

One World The Americas Everywhere UNAMSAT-B successfully reached orbit but broke down after two years of transmissions. Finally, the Mexican Space Agency was formally constituted in 2013. For decades, only the United States and the Soviet Union had governmental space programs, but by 2018 that list had grown to more than 70 national space agencies. In addition to the "big six" (the United States, the Russian Federation, Europe, China, India and Japan), eight Latin American, eight Asian, five Middle Eastern and six African countries now have space agencies. As with Mexico, most of these do not have launch capabilities but depend on international cooperation with

5. It is also telling that this report aired on the same day as a report on tensions between Mexican migrant workers and US unions (González de Bustamante 2012: 127-128). 
the larger agencies to access, develop, build and launch space instruments.

SO FAR FROM GOD, SO CLOSE TO NASA

Located on Avenida Insurgentes, one of Mexico City's main thoroughfares, the Mexican Space Agency (AEM) looks impressive from the outside, covered in glass and steel and sparkling in the sun. From below, the group of antennas that crown the edifice give it a spatial aura. A plaque at street level informs passers-by that the building was designed by architect Juan José Díaz Infante Núñez (1936-2012), who was a consultant for NASA ("Kalikosmia"). However impressive from the outside, AEM employs about sixty people and occupies only two floors of the building. Its official functions are divided into five general areas: the formation of human capital in the field of outer space; scientific research and the development of space technology; industrial and commercial development and competitiveness in the space sector; international affairs and security in space matters; ${ }^{6}$ and financing and information management of space matters. Arguably, the agency has been most successful with its outreach and educational programs, as the budget assigned to the agency has been too small to permit substantial advances in research and development. I interviewed Mario Arreola, the Director of Outreach at the AEM, in 2018. Mario showed me a painting that had won in the 2014 space-themed competition in the children's category. In front of a black, glittery background, the artist painted Earth and its Moon, as well as three artificial satellites in orbit. In the foreground, a young girl with large black eyes dressed in a spacesuit carries a Mexican flag. She climbs a long ladder from Earth towards a space ship which is designed as a Spanish caravel like the one Colon used in his fifteenth-century voyages of "discovery." Mario told me this image represents the Mexican space project that the AEM would like to promote: Mexico advancing toward the future

6. The Director of this area, Rosa María de Arellano y Haro, served as the Chair of the Commission on the Peaceful Uses of Outer Space (COPUOS), part of the United Nations Office for Outer Space Affairs (UNOOSA), until June of 2019. 
One World The Americas Everywhere

of space technology, but without abandoning the knowledge and achievements of its past?

One of the AEM's most important activities has been the creation of a network of collectives and individuals, particularly young Mexicans, interested in the possibilities of outer space. Many of these were inspired when they were children by astronomy, science fiction, or the narrative of Rodolfo Neri Vela, the only Mexican to have been to outer space. Neri Vela, originally from the state of Cuerrero, travelled as a payload specialist on board the space shuttle Atlantis to the International Space Station in 1985. He spent 9.6 days in space and is said to have introduced Mexican tortillas to the astronauts' diet, which do not create crumbs which could damage equipment in low-gravity environments (Kardoudi). The only other person with a claim to have been a Mexican in space is retired NASA astronaut José Hernández Moreno, born in California as the son of migrant workers from Michoacán, Mexico. Hernández, a flight engineer, flew to the International Space Station in 2009 onboard the space shuttle Endeavor. ${ }^{8}$ He spent 13.9 days in space, and was the first person to send tweets in Spanish back to Earth (Hernández Moreno 2011: 178). Hernández went to space as a NASA employee and U.S. citizen; Neri Vela was able to travel to space thanks to an agreement between the Mexican government and NASA, whose main objective was the launching of the telecommunications satellite Morelos. But access to space is limited. Outside of special agreements, being an astronaut requires carrying a passport from a nation with a crewed spaceflight program, an exclusion justified by "reasons of national security" ("Cuía”).

\section{CITIZEN ASTRONAUTS AND ANALOGOUS MISSIONS}

Carmen Félix, a 35-year-old engineer and entrepreneur, is hopeful. Born in Culiacán, Sinaloa, she now lives and works in Amsterdam. She would like to be a 'real' astronaut, but for now is working to be a 'citizen astronaut,' the only option currently available to her, as NASA

7. Other entries in the space art contest make reference to the past through pre-Hispanic rather than colonial imagery.

8. Endeavour was named the ship of eighteenth-century explorer Captain James Cook. It was built to replace the shuttle Challenger which tragically exploded in 1985. 
requires all astronauts who go to space to be American citizens. ${ }^{9}$ After her parents dissuaded her from studying astronomy because, they said, she "would die of hunger, because in Mexico there is no support for science," Carmen began studying international commerce; however, she decided to visit NASA, and her trip coincided with the congress of the International Astronautical Federation. Carmen spoke with a few US astronauts who advised her to study science and engineering if she still wanted to "do something in outer space." Upon returning to Culiacán, Carmen decided to pursue an undergraduate degree in electronic engineering and telecommunications, given its relevance to satellites. After graduation, she received a scholarship and continued her education with a master's degree in space sciences in France, which would eventually lead her to become one of Mexico's first interns at NASA's Ames Research Center, where she worked on projects involving small satellites. The AEM came into being while she was at Ames, and she participated in its consolidation. After her contract with NASA expired, it could not be renewed due to her Mexican citizenship. As the AEM was still in its infancy, however, she was unable to find many work opportunities in her area of expertise in Mexico. Therefore, when given the opportunity to work in the field of space security in the Netherlands, she packed her bags and returned to Europe.

One of her goals is to involve more young Mexicans in the space industry, and she is an active member of the Space Ceneration Advisory Council (SCAC), a global network that seeks to encourage interest in space exploration and its related industries among young people. The SCAC has a voice in the COPUOS of the United Nations, and agreements with "leading space agencies, corporations and organizations from around the world" (SCAC 2020). Carmen is often asked to represent the youth of Mexico and Latin America to governmental and non-governmental institutions, although she laments that, despite the opportunities they have to study in other countries, young Mexicans often return to precarious or non-existent employment prospects, and therefore cannot apply the knowledge they have acquired.10 Although she has not had trouble finding

9. Personal interview with Carmen Félix, Nov. 2018.

10. Another issue is what has been called the "maquilización" of industry: highly qualified recent graduates in Mexico are subcontracted by transnational 
work in the space industry (outside Mexico), Carmen has not lost interest in space travel. Because of this, she "continues to fulfill the requirements," participating in training programs designed to prepare 'citizen astronauts,' an appellation derived from 'citizen scientist,' which refers to a non-professional with a vocation in areas such as astronomy, biology or ecology, and who contributes to the advancement of science by gathering data for research projects in these fields. Citizen science recognizes the contributions of 'lay' or 'amateur' researchers in the construction of knowledge for a more democratically distributed, 'public' science (Gura 2013: 259).

Analogic play-philosophical and pragmatic-is one of the principal motors of the imagination, an approach to new experience and, therefore, of scientific experimentation (Vosniadou and Ortony 1989). It may be used to make comprehensible those things that are difficult to apprehend because they are too far away or because they do not yet exist. Or, it may be used to rehearse experiences that are still impossible or impractical in 'real' life (like calling a desert region of San Luís Potosí 'Cabo Tuna' or being a citizen instead of a 'real' astronaut). In fact, one of the most important activities, both for 'real' and citizen astronauts is the participation in analogous training missions designed to simulate extreme outer space conditions, like those found on a spaceflight or life on the Moon or Mars (Olson 2018). Apollo astronauts did train in a Mexican analogue environment, but Carmen Félix was the first Mexican to participate in a space analogue: a parabolic flight in Russia; as well as projects

One World The Americas Everywhere testing space suits in Spain, Austria and Morocco; a Mars simulation in the Utah desert; and training in a subaquatic module that reproduces the experience of movement in low gravity.

In December of 2018, with Carmen's support the all-Mexican team, MEX-1, was accepted for a mission at the Mars Desert Research Station (MDRS) in Utah. The MDRS is an installation funded by the Mars Society whose stated function is the promotion of the planet Mars as an object of study and eventual destination (Mars Society).In many of the photographs they published of their

companies with very good salaries and benefits, but their work is limited to technical, repetitive activities on a small link in the chain of production. They are rarely allowed to see "the big picture" or contribute significantly in a way commensurate with their skills and knowledge (Nieto 2016). 
mission, team members carry the Mexican flag, as if to plant it on the surface of Mars." I spoke to the team on Skype a week before their trip, and the first thing they did was complain about the slow speed of our connection. "It's not a satellite link, guys," they joked. All were members of the SCAC, and they met during the congress of the International Astronautic Federation held in Guadalajara in 2016. Originally scheduled to go to the MDRS in November of 2017, their mission was postponed for a year due to budgetary problems and the larger crisis in Mexico resulting from the earthquake of September 2017. Like Carmen, the members of MEX-1 spoke of limited opportunities in the fields of science and technology in Mexico. They emphasized the importance of investing in those fields "for the good of the country's future," as well as the political limitations in doing so. These young engineers, who had not been born when Neil Armstrong landed on the Moon or when Neri Vela went into space, echoed Carmen's dream: “It's really hard right now, but why not pave the way so that Mexican astronauts can once again be included in [space] missions?"12 They argue that the Mexican government, through the AEM, should provide more support so that highly qualified young people are not forced to become 'citizen scientists,' or to individually seek professional opportunities outside their home country.

In the context of citizen science, citizenship is a civic, rather than a political category, as it involves the participation in a kind of universal civil society. But it also points to the existence and negotiation of borders, even in the cosmopolitan outer space industry. As Étienne Balibar points out, one is never simply a citizen, but always a citizen of somewhere (2017: 275). For Carmen and the members of MEX-1, being citizen scientists implies a paradox: even as their education includes them in a global community of space professions from which others are excluded, the political limits of citizenship are what prohibit them from being "real" astronauts. They travel on legal visas, study at accredited universities, obtain international grants and scholarships, and speak English. They are "cosmopolitan."

11. See Messeri (2016) for an ethnographic description of the experience of participating in a MDRS mission.

12. Personal interview with members of MEX-1, Nov. 2018. 
But their experience is also necessarily cosmopolitical, transected by borders, identities and representational aspirations.

\section{TECHNOPHILIA AND ASTROCAPITALISM}

In the twenty-first century, beyond individual dreams of traveling to space, or cosmic dreams of a border-free universe, Mexico and Mexicans have largely been drawn to outer space because of the possibility of achieving economic development through technological innovation. Carmen Félix argues that "for each dollar invested in space, there is a gain of eight dollars." Mexico must find an economic niche in the development of satellites or robotics, but "we must be the owners of our own technology" and "think of the future."13 By sending objects rather than humans, Mexico might be capable of "conquering outer space."

Faith in technology as a means of insuring social and economic progress has a long history in Mexico, as illustrated on the exterior and interior walls of the Polyforum in Mexico City. Home to one of the largest murals in the world, The March of Humanity on Earth and Toward the Cosmos, painted by David Alfaro Siqueiros, is composed of a series of allegorical panels that illustrate humanity's social, political and technological evolution. In the culminating panels of the interior vaulted ceiling, the cosmos itself is represented by a pair of astronauts who oversee human progress from above, between the warring symbols of the red star of communism and the eagle of capitalism. These images, included in 1969,

One World The Americas Everywhere were inspired by the Moon landing, an event which, according to the Siqueiros, had the potential to usher in a new era in the history of humanity (Ramos 2016).

Today, faith in technology is stronger than ever, although few refer to the Marxist dialectic upon which Siqueiros based his vision. In Mexico, as in other parts of the world, the aerospace sector has become a key actor in the development of communication and other technologies. Mexican technophiliac dreams can be

13. Personal interview with Carmen Félix, November 2018. I do not know the source of Carmen's calculations about the profits of outer space investments, but one of the members of MEX-1 provided similar statistical data: "Only $11 \%$ of the technology [is] developed for outer space: 89\% stays on Earth" (Personal interview with members of MEX-1, Nov. 2018). 
framed within the context of a new tendency which David Valentine (2012) terms "astrocapitalism." For astrocapitalists, outer space represents a potential niche for "impactful" technological innovation. Space activities in Mexico have required a series of negotiations between the government, private enterprise and universities, generally in collaboration with international institutions and companies. Promotors of the space industry see in technology hope for the country's future: increased employment, a means of monitoring climate change and natural disasters and a way of improving communication and information networks (ProMexico 2017). In the context of technological advances, particularly in light of the increasing miniaturization of technology, the AEM is betting on small satellites as a way of participating in the space industry. In this endeavor, Mexico joins a large group of small space agencies around the world investing in "CanSats," which give students practice in developing satellites, and "CubeSats," fully functioning satellites that weigh little more than 1 kilogram. Although most satellite development programs require economic and technological support from the larger space agencies, the idea is to eventually become technologically autonomous, and not dependent on information provided by US, European, Russian or Chinese satellites (Matthews 2016). In Mexico, one recent project was AztechSat-1, a CubeSat developed by students and researchers from the Popular Autonomous University of Puebla, with the support of NASA and Chicano astronaut José Hernández. Designed to test communications with the commercial satellite network GlobalStar and launched to the International Space Station in December of 2019, AztechSat-1 was touted as the first nanosatellite produced in Mexico to reach outer space.

"Satellites are noble," Genaro, a young engineer with his own start-up company, told me; "they are agnostic." He went on to explain that satellites are useful in all parts of Mexico, even the most isolated regions, for example, by reducing response time to natural disasters. He laments that many people think that spending money on space technology as wasteful, given the many problems Mexico has on the ground. What they do not realize, he argues, is that space technology has any number of earthly applications and can be used to deal with social and environmental 
problems (personal communication, November 2018). His colleague César agrees. Like Neri Vela, César is originally from Guerrero, one of the regions that has been greatly affected by violence and crime during the last decade. He believes that "We should stop being a country of 'made in Mexico' and start being 'designed in Mexico' [...] We should stop doing things 'the Mexican way' and start to be a country that generates value for the world."14

For César, Cenaro and many of their generation, companies like Boeing and Lockheed Martin are models to be followed. If Mexico developed the space industry, the future could see a 'Mexican conquest of space'-neither he nor any of the other young entrepreneurs with whom I spoke found the term "conquest" problematic, despite Mexico's colonial past.

\section{MATTERS OF GRAVITY AND ASTROPOETICS}

Despite the growing dominance of Mexican astrocapitalism, the AEM has also developed alliances with other actors that Spivak might deem "planetary," Stengers "cosmopolitical," and Blumenberg, "astronoetic." Kosmica, for example, is an international institute that often collaborates with the AEM in outreach events. It was founded in 2011 by the Mexican-born artist-magician-hypnotisttheremin-player-astronaut-trainee-spokesperson for ITACCUS (Technical Activities Committee for the Cultural Uses of Space of the International Astronautical Federation) (de la Puente, et al. 2020). Its work revolves around five key themes: creativity,

One World

The Americas

Everywhere earth, future imaginaries, diversity and celebration. Although its members use technology in their work and collaborate with global and national space agencies and organizations, their perspective on space could be characterized as astropoetic.

One of their most suggestive works was Matters of Gravity, a two-year arts and science project reflecting on gravity by its absence, directed by Nahum and Ale de la Puente. The nine Mexican artists (and once scientist) that participated in the project experienced a zero-gravity flight mission at the Yuri Gagarin Cosmonaut Training Centre in Russia. The brief moments of weightlessness "were enough to experiment with eternity, to realise a story,

14. Personal interview with members of MEX-1, Nov. 2018. 
to break a paradigm, to liberate a molecule, to have an illusion, to experience movement without references, to create poetry out of two bodies, to make the useless become useful and to search for an impossible embrace" (de la Puente 2015). There was also a piñata. The project resulted in a collective exhibition that toured at museums in Mexico City, Jalisco, Moscow, Slovenia, and Texas, and included video, performance, sculpture, drawing and installation.

Although 'Mexican things' like the the piñata were undeniably present, the project became a way for most of the artists and their publics to think beyond borders, using gravity and its absence as a metaphor for untethered relationships that have more to do with a planetary, cosmopolitical, astronoetic experience of space than a way of trying to see outer space "from Mexico." That said, it is impossible to completely break one's territorial, earthly bonds, to become completely untethered.

\section{CONCLUSIONS}

Outer space demands both a wide and a narrow view of the cosmos from particular places, or, in the case of satellites, of particular places from the cosmos. Earthly imaginaries, discourses and practices that revolve around outer space do nothing to resolve the tensions between cosmos and polis, the detached and the engaged, the uninhabitable and the rooted, the planet and the globe; indeed, outer space proves to be just as plagued and fragmented by borders as the Earth, marked by practices of inclusion and exclusion. The possibilities of shared extraterrestrial utopias (philosophical, political, scientific or economic) are tempered by the realities of terrestrial conflicts and commitments. The universal produces unease, Balibar tells us, and does not make differences disappear (2017: 276). Citizens belong to communities, not the universe, although political modernity declares that they also inherit common rights "from which no human can be excluded" (2017: 276). Mexican space professionals-government officials, students, entrepreneurs, scientists, artists-inhabit contact zones in which international relations and cosmopolitan and/or cosmopolitical actions are everyday experiences. But they are also daily faced with the differential "possibilities of human actualization" produced by earthly situatedness. In this sense, 
One World The Americas

Everywhere

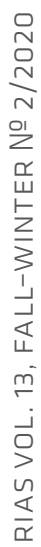

Mexico is particularly complex: a periphery, but also a center, not non-Western, but also not-not non-Western. The actors I have included in this text do not deny their difference, but they do seek recognition as peers, a position which international 'collaborations' may promise, but rarely deliver. Here, I have tried to think astronoetically by looking at borders and contact zones on Earth and in space. Like Bruno Latour I ask, "Whose cosmos?" And like Gayatri Spivak I answer that still, despite everything, there is hope in the planetary, uncanny as it may be. 
Arendt, Hannah. "The Conquest of Space and the Stature of Man." New Atlantis, núm. 18, 2007, pp. 43-55. www.thenewatlantis.com/ publications/the-conquest-of-space-and-the-stature-ofman

Arreola Santander, Mario. "Astronautas del Programa Apolo en México." Hacia el espacio, vol. 79, 2017. haciaelespacio.aem.gob.mx/ revistadigital/articul.php?interior $=523$

Arreola, Mario. Personal Interview. Nov. 2018.

Balibar, Étienne. Citizen Subject: Foundations for Philosophical Anthropology. Translated by Steven Miller, Fordham UP, 2017.

Chakrabarty, Dipesh. Provincializing Europe: Postcolonial Thought and Historical Difference. Princeton UP, 2000.

Durrani, Haris A. "The Bogotá Declaration: A Global Uprising?" Uprising 1313: 13 Seminars at Columbia, Columbia Center for Contemporary Critical Thought, Columbia University, 2018 blogs. law.columbia.edu/uprising1313/haris-a-durrani-the-bogotadeclaration-a-global-uprising/?cn-reloaded=1. Accessed 30 Jun. 2019.

Félix, Carmen. Personal Interview. Nov. 2018.

Gagarin, Yuri and Valentina Tereschkova. Interview by Radio UNAM. "Radio UNAM entrevista a Yuri Gagarin y Valentina Tereschkova" 1963. 24 July 2018, https://www.archivosonoro.org/ archivos/radio-unam-entrevista-a-yuri-gagarin-y-valentinatereschkova/. Accessed 10 Dec. 2019.

González de Bustamante, Celeste. "Muy Buenas Noches:" Mexico, Television and the Cold War. U of Nebraska P, 2012.

"Guía para convertirte en astronauta de la NASA." viveUSA, 02 May 2015, https://www.viveusa.mx/educacion/guia-para-convertirte-en-astronauta-de-la-nasa. Accessed 20 Nov. 2019.

Gura, Trisa. "Citizen Science: Amateur Experts." Nature, vol. 496, 2013. pp. 259-261. https://doi.org/10.1038/nj7444-259a

Harries, Karsten. Infinity and Perspective. Massachusetts Institute of Technology, 2001. 
Heidegger, Martin. "'Only a God Can Save Us': The Spiegel Interview." Heidegger: The Man and the Thinker, edited by Thomas Sheehan. Transaction Publishers, 2011, pp. 45-67.

Hernández Moreno, José. El cosechador de estrellas. Grupo Editorial Patria, 2011.

Ingold, Tim. "Clobes and Spheres: The Topology of Environmentalism." The Perception of the Environment: Essays on Livelihood, Dwelling and Skill. Routledge, 2000.

"Kalikosmia: el ideal de una vivienda mexicana." Código, 23 Feb. 2017. https://revistacodigo.com/destacado-casa-kalikosmicaideal-una-vivienda-mexicana/. Accessed 02 Dec. 2019.

Kardoudi, Omar. "Why Astronauts Eat Tortillas Explained in One Comic." Cizmodo, 19 Jan. 2015, https://gizmodo.com/why-astronauts-eat-tortillas-in-space-explained-in-one-1680376949. Accessed 30 Jun. 2019.

Kohut, Matthew. "Shaping the Space Age: The International Geophysical Year." Ask Magazine. NASA vol. 32, pp. 29-30. appel.nasa. gov/2008/09/01/shaping-the-space-age-the-internationalgeophysical-year/. Accessed 14 Jan. 2020.

Krige, John. "Fifty Years of NASA and the World." NASA in the World: Fifty Years of International Collaboration in Space, edited by John Krige, et al. Palgrave Macmillan, 2013, pp. 3-22.

Latour, Bruno. "Whose Cosmos, Which Cosmopolitics?: Comments on the Peace Terms of Ulrich Beck" Common Knowledge, vol.

One World The Americas Everywhere 10, no. 3, 2004, pp. 450-462. muse.jhu.edu/article/171401

Listner, Michael. "The Moon Treaty: Failed International Law or Waiting in the Shadows?" The Space Review. Monday, 24 Oct. 2011, https://www.thespacereview.com/article/1954/1. Accessed 14 Jan. 2020.

Mars Society, The. "About the MDRS." Mars Desert Research Station, The Mars Society, http://mdrs.marssociety.org/. Accessed 14 Jan. 2020.

Matthews, Chris. "Why Ghana Started a Space Program." Vice, 05 January 2016, https://www.vice.com/en_us/article/nz7bnq/ why-ghana-started-a-space-program. Accessed 14 Jan. 2020.

Matthews, Gordon, et al., editors. Globalization from Below: The World's Other Economy. Routledge, 2012. 
MEX-1, Members of. Personal Interview. Nov. 2018

Messeri, Lisa. Placing Outer Space: An Earthly Ethnography of Other Worlds. Duke UP Books, 2016.

Mignolo, Walter. "Cosmopolitan Localism: A Decolonial Shifting of Kantian's Legacies." Localities, vol. 1, 2011, pp. 11-45.

Montaño Barbosa, Alejandro. "La trayectoria de México en la exploración espacial." 2015. www.cienciamx.com/index.php/ciencia/ universo/4714-historia-de-la-astronautica-en-mexico-delsputnik-i-a-la-agencia-espacial-mexicana

Nieto, Raul. "Trabajo en la globalidad hegemónica. Performance laboral en México y Guatemala." Revista Andaluza de Antropología, no. 11, 2016, pp. 15-43. dialnet.unirioja.es/servlet/ articulo? codigo $=5666545$

Olson, Valerie. Into the Extreme: US Environmental Systems and Politics beyond Earth. U of Minnesota P, 2018.

Olvera, Carlos. Mejicanos en el espacio. Editorial Diógenes, 1968.

ProMéxico. Plan de Órbita 2.0. Mapa de Ruta del Sector Espacial Mexicano. 2017. www.promexico.gob.mx/documentos/biblioteca/ plan-orbita.pdf

de la Puente, Ale, artistic director. "Matters of Gravity." 2015. The Arts Catalyst, https://www.artscatalyst.org/sites/default/files/ TheMattersOfGravityAC.pdf

Ramos, Maricarmen. Siqueiros humanista: La marcha de la humanidad. Ibukku, 2016.

Ribeiro, Gustavo Lins. "Post-imperialism: A Latin American Cosmopolitics." Brazil and the Americas: Convergences and Perspectives, edited by Peter Birle, Sérgio Costa and Horst Nitschack, Iberoamericana/Vervuert, 2008, pp. 31-50.

Robbins, Bruce. "Introduction Part I: Actually Existing Cosmopolitanisms." Cosmopolitics: Thinking and Feeling beyond the Nation, edited by Bruce Robbins and Pheng Cheah. U of Minnesota P, 1998, pp. 1-19.

Robbins, Bruce and Paulo Lemos Horta. Introduction. Cosmopolitanisms. New York UP, 2017, pp. 1-20.

Space Generation Advisory Council (SGAC), 2020. https://spacegeneration.org/. Accessed 14 Jan. 2020. 
One World The Americas Everywhere

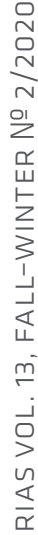

Spivak, Gayatri Chakravoty. "Planetarity." Death of a Discipline. Columbia UP, 2003, pp. 71-102.

Stengers, Isabelle. "The Cosmopolitan Question." Cosmopolitics II. The $U$ of Minnesota P, 2011, pp. 351-362.

United Nations Office for Outer Space Affairs (UNOOSA). "Space Law Treaties and Principles." International Space Law: United Nations Instruments, United Nations, May 2017. https:// www.unoosa.org/oosa/en/ourwork/spacelaw/treaties.html. Accessed 10 Jan. 2020.

Urrutia Fucugauchi, Jaime. “El Año Geofísico Internacional 1957-1958 y los programas de investigación interdisciplinaria en el inicio del siglo XXI". GEOS, June 1999, pp. 128-131. ugm.org.mx/publicaciones/geos/pdf/geos99-2/geofisico-19-2.pdf

Valentine, David. "Exit Strategy: Profit, Cosmology, and the Future of Humans in Space." Anthropological Quarterly, vol. 85, no. 4, 2012, pp. 1045-1067. https://doi.org/10.1353/anq.2012.0073

Vosniadou, Stella and Andrew Ortony. "Similarity and Analogical Reasoning: A Synthesis." Similarity and Analogical Reasoning, edited by Stella Vosniadou and Andrew Ortony. Cambridge UP, 1989, pp. 1-18. 